\title{
Recent advances in the role of excitation-inhibition balance in motor recovery post-stroke
}

\author{
Ioana-Florentina Grigoras ${ }^{1 *}$ Charlotte J. Stagg ${ }^{1}$ \\ ${ }^{1}$ Wellcome Centre for Integrative Neuroimaging, FMRIB, Nuffield Department of Clinical Neurosciences, University of Oxford; Medical Research Council \\ Brain Network Dynamics Unit, University of Oxford, Oxford, UK
}

\begin{abstract}
Stroke affects millions of people worldwide each year, and stroke survivors are often left with motor deficits. Current therapies to improve these functional deficits are limited, making it a priority to better understand the pathophysiology of stroke recovery and find novel adjuvant options. The excitation-inhibition balance undergoes significant changes post-stroke, and the inhibitory neurotransmitter $\gamma$-aminobutyric acid (GABA) appears to play an important role in stroke recovery. In this review, we summarise the most recent studies investigating GABAergic inhibition at different stages of stroke. We discuss the proposed role of GABA in counteracting glutamate-mediated excitotoxicity in hyperacute stroke as well as the evidence linking decreased GABAergic inhibition to increased neuronal plasticity in early stroke. Then, we discuss two types of interventions that aim to modulate the excitation-inhibition balance to improve functional outcomes in stroke survivors: non-invasive brain stimulation (NIBS) and pharmacological interventions. Finding the optimal NIBS administration or adjuvant pharmacological therapies would represent an important contribution to the currently scarce therapy options.
\end{abstract}

\section{Keywords}

GABA, stroke, motor recovery, TMS, MRS, NIBS, pharmacological intervention

\section{Peer Review}

The peer reviewers who approve this article are:

1. Winston D Byblow, Centre for Brain Research, The University of Auckland, Auckland, New Zealand Competing interests: No competing interests were disclosed.

2. Andrew N Clarkson, Department of Anatomy, Brain Health Research Centre and Brain Research New Zealand, University of Otago, Dunedin, New Zealand

Competing interests: No competing interests were disclosed. 
*Corresponding author: Ioana-Florentina Grigoras (ioana.grigoras@ndcn.ox.ac.uk)

Competing interests: The authors declare that they have no competing interests.

Grant information: CJS holds a Sir Henry Dale Fellowship, funded by the Wellcome Trust and the Royal Society (102584/Z/13/B). IG was funded by a studentship from the Dulverton Trust, Clarendon Fund and St John's College, and University of Oxford.

The funders had no role in study design, data collection and analysis, decision to publish, or preparation of the manuscript.

Copyright: (C) 2021 Grigoras IF et al. This is an open access article distributed under the terms of the Creative Commons Attribution License, which permits unrestricted use, distribution, and reproduction in any medium, provided the original work is properly cited.

How to cite this article: Grigoras IF and Stagg CJ. Recent advances in the role of excitation-inhibition balance in motor recovery post-stroke. Faculty Reviews 2021 10:(58) https://doi.org/10.12703/r/10-58

Published: 23 June 2021, Faculty Reviews 10:(58) https://doi.org/10.12703/r/10-58 


\section{Introduction}

Ten million people worldwide have a stroke each year ${ }^{1}$, making stroke a leading cause of both morbidity and mortality ${ }^{2,3}$, with survivors often left with motor impairments that limit their independence ${ }^{1,4}$. Not only is stroke associated with life-changing challenges for the individual and their family ${ }^{5}$ but also it comes with a high economic cost. In 2012, stroke cost the USA alone over $\$ 30$ billion, a figure predicted to triple by $2030^{6,7}$.

Reperfusion therapy has transformed acute stroke care over the last decade ${ }^{8}$, contributing to substantially reduced mortality rates $^{1}$. However, over half of stroke survivors require rehabilitation for residual motor deficits ${ }^{9,10}$. Currently, the gold standard interventions for motor rehabilitation are limited to physical/ occupational therapies: patients are given task-specific training ${ }^{11}$, which focuses on gaining new motor skills, constraint-induced movement therapy $(\text { CIMT) })^{12}$, or robotic therapy ${ }^{13,14}$. Even after physical therapy, patients may still have motor deficits, deeming the motor recovery incomplete. All current therapies depend on performing repeated movements, limiting their utility in people with severe motor impairments who most require intervention. Therefore, developing novel approaches to enhance the benefits of physiotherapy, particularly for patients with severe residual deficits, is a substantial unmet clinical need. To do this, we need to understand the neural mechanisms of underlying post-stroke motor recovery.

The neural mechanisms of post-stroke recovery have been extensively studied, both in the acute, post-ischaemic period and in the chronic phase. Of these, excitation-inhibition balance appears to be central. Physiologically, both glutamate and $\gamma$-aminobutyric acid (GABA), the major excitatory and inhibitory neurotransmitters, are tightly regulated ${ }^{15}$. However, after a stroke, complex changes in GABAergic regulation occur in both stroke survivors and animal models, which are likely central to functional improvement in recovery after stroke ${ }^{16,17}$. Indeed, GABA has been shown to regulate neuroplasticity in the motor cortex in both healthy animal models and humans $^{18,19}$. The modulation of GABAergic signalling is therefore promising for developing novel therapies.

Here, we first discuss how neurotransmitters can be quantified in humans. Then, we review the role of excitation-inhibition balance in the pathophysiology of stroke in both humans and animal models in each stage of stroke recovery. Finally, we describe different putative interventions, which aim to modulate the excitation-inhibition balance in order to improve motor recovery, and discuss what questions remain to be answered.

\section{GABA quantification in humans}

GABA can be quantified in humans using transcranial magnetic stimulation (TMS), magnetic resonance spectroscopy (MRS), and positron emission tomography (PET).

\section{Transcranial magnetic stimulation}

TMS has been used extensively to investigate cortical excitability and intracortical inhibition in stroke patients ${ }^{20}$. Briefly, an electromagnetic coil is positioned on the scalp over the primary motor cortex (M1), which causes a rapidly changing magnetic pulse to induce an electric current in M1 neurons. If the current is large enough, this causes neuronal depolarisation and subsequent muscle contraction, which can be observed as motor-evoked potentials (MEPs) via electromyography (EMG). TMS quantifies overall corticospinal excitability ${ }^{21}$ and can also estimate synaptic activity reasonably specifically by using paired pulses with different interstimulus intervals (ISIs). The two main classes of GABA receptors, GABA $\mathrm{A}_{\mathrm{A}}$ and $\mathrm{GABA}_{\mathrm{B}}$, can be at least mostly distinguished using quite different stimulus paradigms. $\mathrm{GABA}_{\mathrm{A}}$ receptor activity can be measured with an ISI of 1-5 $\mathrm{ms}$ (short-interval intra-cortical inhibition $[\mathrm{SICI}])^{22}$ and $\mathrm{GABA}_{\mathrm{B}}$ receptor activity with an ISI of 50-200 ms (long-interval intra-cortical inhibition [LICI] $)^{23}$.

Even if TMS measurements are widely used to study excitability and inhibition, TMS remains a noisy technique ${ }^{24}$. To get a robust measurement, the mean of a large number of measurements is calculated ${ }^{25}$. The quality of the TMS measurements is also dependent on the experimenter's proficiency, which cannot be assessed from the data. Finally, acquiring TMS measurements in stroke survivors is difficult, as corticospinal tract damage reduces MEPs. Therefore, TMS studies in stroke patients are biased towards patients with mild and moderate motor impairments.

\section{Proton magnetic resonance spectroscopy}

Proton MRS ( $\left.{ }^{1} \mathrm{H}-\mathrm{MRS}\right)$ allows reliable and non-invasive quantification of neurochemicals in vivo ${ }^{26}$. ${ }^{1} \mathrm{H}-\mathrm{MRS}$ can provide measurements of both glutamate and GABA but with limited spatial and temporal resolution: MRS quantifies the total amount of a neurochemical in a relatively large MRS voxel of interest $\left(8-15 \mathrm{~cm}^{3}\right)$, acquired over minutes. Both glutamate and GABA are important brain metabolites; however, establishing whether the MRS-derived metrics relate to metabolism, neurotransmission, or both is not possible.

It is not clear how MRS and TMS metrics relate. Multi-modal TMS and MRS studies found no link between MRS-derived GABA concentrations ([GABA]) and TMS measures of phasic (synaptic) inhibition ${ }^{27-30}$. A relationship has been proposed between [GABA] in M1 and what is believed to be a TMS measure of extrasynaptic, tonic inhibition ${ }^{27,31}$, but this result has not been replicated in recent studies ${ }^{29,30}$.

\section{Positron emission tomography}

PET uses radioactive tracers to measure specific biochemical processes. The radioactive tracers do not interfere with physiological functions, having a relatively short half-life, and can be extremely biochemically specific. While PET does not have 
good spatial or temporal resolution, it has provided important insights into stroke pathophysiology, such as differentiating between the stroke core and penumbra in humans ${ }^{32}$.

\section{Excitation-inhibition balance in stroke pathophysiology}

\section{Stages of stroke recovery in humans}

A framework has been recently proposed to describe the stroke recovery timeline ${ }^{33}$. In humans, stroke can be classified into four stages: hyper-acute (0-24 hours post-stroke), acute (1-7 days post-stroke), subacute (early subacute 7 days-3 months; late subacute 3-6 months post-stroke), and chronic (more than 6 months post-stroke), each denoted by distinct pathogenic mechanisms. Briefly, hyper-acute stroke is characterised by increased excitability due to glutamate-mediated excitotoxicity, acute and early sub-acute stroke (or early stroke) by reduced intracortical inhibition (hypothesised to support neuronal plasticity) and a significant recovery of motor functions, and chronic stroke by a normalisation of intracortical inhibition and more stable motor performance.

It is unclear how these stages in human recovery map onto recovery stages in animal models. In rodents, the hyper-acute phase is likely to occur in the first few hours after stroke, a timescale broadly similar to that in humans. However, this is dependent on the stroke model being used. In rodents, the post-ischaemic "sensitive period", putatively the equivalent of early stroke in humans, lasts for the first 4 weeks. This period is characterised by enhanced long-term potentiation, increased cortical excitability, and decreased inhibition along with increased dendritic spine formation and axonal sprouting, creating a pro-plastic environment ${ }^{34}$. Whether this is recapitulated in humans is not yet known, though in humans the rate of motor recovery peaks around 3 months after stroke, whereas this is seen at approximately 4 weeks in rodents ${ }^{35}$, suggesting the periods may have similarities.

\section{Hyper-acute stroke}

No studies have investigated excitation-inhibition balance this early after stroke in humans, likely because of survivors' complex medical needs at this time. However, we know from animal models and in vitro studies that ischaemia leads to neuronal death primarily via glutamate-mediated excitotoxicity ${ }^{36,37}$, which would lead to an increase in the excitation-inhibition ratio. In line with this, an in vivo MRS study in rats reported increased glutamate and taurine at 2 hours post-stroke ${ }^{38}$. Indeed, in humans, early mobilisation (within the first 24 hours after the stroke) led to worse outcomes at 3 months $\mathrm{s}^{3,39}$.

However, a recent ex vivo MRS study in rodents demonstrated decreased glutamate in the ipsilesional hemisphere 1 hour after stroke, reaching a minimum after 24 hours. GABA, glycine, and lactate were all significantly increased in the ipsilesional hemisphere during this timeframe, with GABA levels peaking 3 hours after stroke ${ }^{40}$. These results are unexpected; it is possible that different techniques used to perfuse and fix the tissue samples might affect ex vivo measurements.
GABA counteracts the excitotoxic activity of glutamate and has therefore been hypothesised to be neuroprotective. Preclinical studies using benzodiazepines, positive allosteric modulators of the $\mathrm{GABA}_{\mathrm{A}}$ receptor ${ }^{41}$, demonstrated a decrease in ischaemic damage and improved motor rehabilitation in both rodents and non-human primates ${ }^{42,43}$. However, the beneficial effect of benzodiazepines has not been replicated in clinical trials, as reported by a recent Cochrane systematic review. Patients who received benzodiazepines within 12 hours of symptom onset showed no significant difference in recovery compared to placebo $^{44}$.

Benzodiazepines are commonly prescribed to older adults ${ }^{45,46}$, meaning that some patients were taking benzodiazepines before their stroke. Despite promising evidence from the animal literature, patients who were taking benzodiazepines before stroke had a significantly higher mortality and worse functional outcomes 3 months after stroke ${ }^{47}$. However, though the authors tried to eliminate selection bias, this result may be partly biased by the pre-existing comorbidities that led to the need for benzodiazepine treatment.

Taken together, it is likely that human pathophysiology in the hyper-acute phase is more complex than the pathophysiological changes reported in animal stroke literature. Gaining more insight into the pathophysiology of hyper-acute stroke is necessary in order to provide an alternative therapy for patients who cannot receive reperfusion therapy.

\section{Acute and sub-acute stroke}

Most spontaneous recovery occurs in the acute and early sub-acute stages ${ }^{33,35,48}$. The first 3 months post-stroke are likely to be characterised by neurochemical changes that support neuronal plasticity and spontaneous recovery. Therefore, here we will refer to the acute and early sub-acute stages together as "early stroke".

Early stroke in humans is likely to be characterised by mechanisms and processes similar to those of the peri-ischaemic sensitive period in rodents ${ }^{15}$, but a lack of cross-species tools means that validating this link is difficult. MRS is a potential modality that might allow relatively direct comparison between rodent and human models, though acquisition protocols and tissue preparation may vary considerably between species. One of the clear findings from the animal literature is the increase in extrasynaptic $\mathrm{GABA}_{\mathrm{A}}$ tonic inhibition in the peri-infarct area ${ }^{17}$. However, ex vivo ${ }^{1} \mathrm{H}-\mathrm{MRS}$ in rodents demonstrated a significant decrease in NAA, GABA, and glutamate and an increase in glutamine, myo-inositol, and lactate in the ipsilesional hemisphere 7 days after stroke ${ }^{49}$, suggesting that the synthesis of both glutamate and GABA from glutamine may be decreased. It is not clear what effect this change in metabolites 7 days after stroke would have on overall excitation-inhibition balance.

In early stroke in humans, TMS studies demonstrate a reduced excitation-inhibition ratio that increases over time. A recent 
meta-analysis concluded that thresholds were higher in the ipsilesional hemisphere compared to controls, indicating, as expected, a lower excitation-inhibition ratio in the affected hemisphere post-stroke ${ }^{50}$. It is not clear what drives this decreased excitation-inhibition balance: as might be predicted using PET, GABA A activity was shown to be increased at 1 month post-stroke, decreasing to normal at 3 months post-stroke ${ }^{51}$. However, TMS metrics show a significant reduction in GABA $_{\mathrm{A}}$ activity (SICI) in the ipsilesional hemisphere compared to both the contralesional hemisphere and healthy age-matched controls $^{50}$.

Furthermore, in a recent relatively small study, MRS-derived measurements of [GABA] in ipsilesional M1 were not significantly different from those in healthy age-matched controls, but $[\mathrm{GABA}]$ in the contralesional M1 was significantly lower, leading to an overall higher excitation-inhibition ratio $^{52}$. Interpretation of this result is not simple: the authors also reported higher $\mathrm{GABA}_{\mathrm{B}}$ activity (LICI) in both hemispheres compared with controls, in contradiction to previous studies ${ }^{53,54}$. Compared with controls, there was also an increase in $1 \mathrm{~ms}$ SICI, a putative measure of extra-synaptic activity, in the ipsilesional hemisphere at 6 weeks post-stroke, though this was not present at either 2 weeks or 12 weeks post-stroke ${ }^{52}$.

It is difficult to explain why during early stroke patients seem to have both a lower excitation-inhibition ratio and lower intracortical inhibition, especially since there are no significant differences in TMS- or MRS-derived metrics of glutamate activity. Likely, the mechanisms regulating the excitation-inhibition balance are more complex than simply expecting that a change in inhibition would produce a proportional change to the overall excitation-inhibition ratio. Particularly, different aspects of inhibitory signalling (tonic versus phasic inhibition; synaptic $\mathrm{GABA}_{\mathrm{A}}$ or $\mathrm{GABA}_{\mathrm{B}}$ receptors) may affect the excitation-inhibition balance in different ways. Pharmacological studies enable modulation of these processes separately, at least to some degree, which may allow researchers to tease apart how changes in either excitation or inhibition affect the overall excitation-inhibition balance.

Conducting research with early stroke patients is difficult, as there are several challenges associated with their care and health status at this point, including difficulties recruiting patients owing to poor recovery, loss of contact because of transfer to a different centre/physiotherapy facility, heterogeneity of comorbidities, medication and recovery, and difficulties in travelling from their home to the research facility, meaning that large samples are often difficult to achieve for individual studies. However, multi-centre studies are hampered by a lack of standardisation in the research methods themselves, for example defining appropriate inclusion criteria when residual functional impairments are not yet clear. In particular, neuroimaging studies in early stroke often rely on clinical imaging, which is not standardised across centres, making multi-centre studies difficult. One way to address some of these challenges is to have a recognised framework of definitions and standards for stroke recovery, such as the one that has been introduced by the Stroke Recovery and Rehabilitation Roundtable taskforce ${ }^{33}$. Adoption of this framework will allow more multi-centre trials to be conducted, ultimately increasing both the quantity and the quality of the data being collected.

\section{Chronic stroke}

Chronic stroke patients are unlikely to improve their motor function after approximately 6 months post-stroke unless given rehabilitation, suggesting that the neurochemical milieu is significantly different in this period compared to in early stroke. However, characterising this has proved difficult: although the majority of studies in humans occur in the chronic phase, there is a paucity of data from animal models regarding excitation-inhibition balance. TMS studies have shown that, as in the early stages of stroke recovery, overall cortical excitability is decreased in the ipsilesional hemisphere compared to both the contralesional hemisphere and healthy age-matched controls $^{50}$. A number of human MRS studies have demonstrated a decrease in [GABA] in the ipsilesional hemisphere at rest in chronic stroke patients ${ }^{55-57}$. However, GABA A $^{- \text {mediated }}$ inhibition measured using SICI does not differ significantly between the ipsilesional hemisphere and either the contralesional hemisphere or healthy age-matched $\operatorname{controls}^{50}$. This pattern contrasts with that seen in early stroke, when GABAergic inhibition is decreased in the ipsilesional hemisphere, but is consistent with the time course for spontaneous functional improvements. Therefore, it is plausible that decreased inhibition in early stroke may play an important role in supporting neuroplasticity and, as inhibition normalises, the potential for spontaneous motor recovery reduces. Recent preliminary evidence supports this role for $\mathrm{GABA}_{\mathrm{A}}$-mediated inhibition by demonstrating a relationship between lower inhibition and better hand function post-stroke ${ }^{58}$. Improvements in function following rehabilitation interventions at this stage also appear to be related to changes in inhibition. The relative improvement in function after 2 weeks of CIMT was positively correlated with decreases in MRS-derived [GABA] in ipsilesional $\mathrm{M}^{56}$. Moreover, baseline $[\mathrm{GABA}$ ] predicted subsequent response to a non-invasive brain stimulation (NIBS) intervention ${ }^{59}$.

However, as with all clinical studies, the population studied is heterogeneous and measures are indirect, meaning that drawing firm conclusions from these data can be difficult. In particular, it is likely that rehabilitation interventions modulate excitation-inhibition balance ${ }^{60-63}$; without controlling for this, it is impossible to disambiguate spontaneous changes from those induced by motor training.

Multimodal studies are vital to interpret the potentially conflicting results between modalities. A recent study using both TMS and MRS described no significant differences in TMS-derived measurements of GABA $_{A}$ activity between patients and controls ${ }^{57}$. However, the authors reported a significant reduction in [GABA] in both hemispheres in the same patients. There was no correlation between neurophysiological measurements of $\mathrm{GABA}_{\mathrm{A}}$ and $\mathrm{GABA}_{\mathrm{B}}$ receptor inhibition and 
MRS-derived [GABA], making it difficult to distinguish which GABA compartments are measured with MRS, since they do not relate to the neurotransmitter's activity at its receptors. This raises an important question for the understanding of brain physiology, which should be addressed by future research: do MRS neurochemical metrics relate more closely to neurotransmitter activity or to metabolism?

One promising avenue for future research highlighted by Mooney and colleagues was the role of the $\mathrm{GABA}_{\mathrm{B}}$ receptor in the excitation-inhibition balance in chronic stroke. TMS measures of $\mathrm{GABA}_{\mathrm{B}}$-mediated inhibition have been found to be higher in the ipsilesional hemisphere, and late cortical disinhibition (LCD), a measure of presynaptic $\mathrm{GABA}_{\mathrm{B}}$ receptors normally present in healthy adults ${ }^{64}$, had an inhibitory effect in the ipsilesional hemisphere in chronic stroke ${ }^{57}$ LCD was the only metric that correlated with clinical impairment and functional scores, possibly suggesting a central role for $\mathrm{GABA}_{\mathrm{B}}$ signalling.

All of the studies discussed above relate to measures of GABAergic inhibition at rest. However, GABA $A_{A}$-mediated inhibition decreases during healthy movement preparation, allowing movement to occur ${ }^{65}$. An abnormal persistence of GABA-mediated inhibition during movement preparation has been reported in chronic stroke patients ${ }^{66}$. It is not clear whether this is a pathological or compensatory change, but a recent study in healthy subjects demonstrated that as subjects

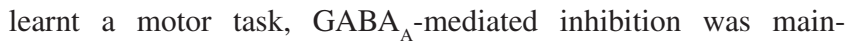
tained for longer ${ }^{67}$, possibly suggesting that the maintenance of pre-movement inhibition may be a compensatory phenomenon.

There is no evidence of neurophysiological changes in the contralesional hemisphere and healthy age-matched adults in either early or chronic stroke ${ }^{50}$, suggesting that the pathological mechanisms of stroke are limited to the affected hemisphere. Supporting the presence of a pro-plastic environment in the ipsilesional hemisphere would therefore be more likely to be beneficial for motor recovery than neuromodulation of the contralesional hemisphere.

\section{Modulating GABAergic inhibition in stroke}

Two major classes of interventions have been employed to modulate GABAergic inhibition and promote recovery post-stroke: NIBS and pharmacological agents.

\section{Non-invasive brain stimulation}

NIBS can be used either to provide neurophysiological measurements of cortical excitability and intracortical inhibition, as described above for TMS, or to modulate neuronal activity, usually using repetitive TMS (rTMS) or transcranial electric stimulation in the form of transcranial direct current stimulation (tDCS; see 68 for a full description $)^{69}$.

NIBS aims to promote a pro-plastic environment, and its effect on motor recovery post-stroke has been investigated in numerous studies. This vast body of work is not within the scope of this review. Several recent reviews and meta-analyses have discussed the role of NIBS in motor recovery post-stroke ${ }^{70}$, including the effect of rTMS on motor recovery after stroke ${ }^{71,72}$, the effect of tDCS combined with motor practice on stroke recovery ${ }^{73,74}$, and the role of NIBS on recovery of fine motor functions after stroke ${ }^{75}$. Overall, evidence points to a beneficial effect for NIBS in stroke recovery, especially when associated with physical rehabilitation, but further randomised, sham-controlled studies are needed to address the high heterogeneity of NIBS techniques as well as find the optimal start, duration, and frequency of stimulation administration.

\section{Pharmacological interventions}

Several compounds have recently shown promising results in animal models of stroke but have yet to complete clinical trials.

Recently, S44819, a selective antagonist of the extrasynaptic $\mathrm{GABA}_{\mathrm{A}} \alpha 5$ receptor with a good safety profile for human use, was developed ${ }^{76,77}$. Reducing pathologically increased tonic inhibition with S44819 during early stroke led to better motor function in mice ${ }^{78}$, with associated increased neuronal viability, decreased peri-infarct astrogliosis, increased brain capillary density, and higher proliferation of neural precursor cells. Despite this promising evidence from preclinical studies, a recent phase II clinical trial reported no significant difference in overall post-stroke recovery after long-term administration of S44819 in early stroke compared with placebo $^{79}$. However, the modified Rankin Scale, the primary endpoint measure, has low sensitivity, and the absence of measurement on motor-specific scales makes it hard to detect small improvements in motor functions. Additionally, to increase recruitment, this clinical trial included all patients who had suffered a cortical or combined cortical-subcortical ischaemic stroke between 2 and 6 days before inclusion in the study. In animal stroke models, S44819 is shown to improve motor function in a lesion that includes the motor cortex, so it is possible that recruiting only patients with M1 lesions may have shown better outcomes. Additionally, the duration of drug administration for each patient was not taken into account, and no TMS or MRS data were collected to confirm that S44819 administration in stroke patients leads to similar changes in GABAergic inhibition as seen in healthy volunteers. Lastly, it is worth noting that sex hormones influence neurotransmitter release, and the animal stroke study used only male mice. Even if the median age of the patients included in the clinical trial is over 67 years old, which would make the majority of female patients included postmenopausal, a potential difference in efficacy between sexes cannot be excluded. Therefore, it is probably too early to dismiss this approach as a line of potential therapy.

S44819 is not the only GABA-modulating drug to be trialled to normalise the increased tonic inhibition present after stroke. Preclinical stroke studies reported a significant improvement of motor functions in rodents after administration of $\alpha-\mathrm{GABA}_{\mathrm{A}}$ receptor inverse agonists like L-655,708 $17,80-82$ or methyl-6,7-dimethoxy-4-ethyl-beta-carboline-3-carboxylate 
$(\mathrm{DMCM})^{83}$. Owing to safety issues regarding the need to be dissolved in DMSO, L-655,708 will never be used in humans, but DMCM is yet to be trialled in humans.

Data from animal studies using L-655,708 show that a small GABA receptor occupancy (7-14\%) is needed to see a strong effect on post-stroke recovery. Therefore, there is a lot of debate on whether a full antagonist or a negative allosteric modulator (NAM), which would allow for titration of receptor occupancy, might be better to use. Further studies could combine pharmacological interventions with neuroimaging or brain stimulation to test this hypothesis.

A potential role for the $\delta$-GABA $\mathrm{A}_{\mathrm{A}}$ receptors, which are primarily found extrasynaptically, has been proposed in motor stroke recovery after administration of the $\delta-\mathrm{GABA}_{\mathrm{A}}$ receptor-positive allosteric modulator DS2 led to decreases in infarct size and significant motor improvements in rodents ${ }^{84}$. The beneficial role of flavonoids, such as 2'-methoxy-6-methyflavone (2'MeO6MF), on motor recovery after stroke has also been linked to $\delta-\mathrm{GABA}_{\mathrm{A}}$ receptors, as the effect was lost in $\delta-\mathrm{GABA}_{\mathrm{A}}$ receptor knock-out animals ${ }^{85}$.

Zolpidem is a hypnotic and selective non-benzodiazepine GABA-positive allosteric modulator for the $\alpha 1$ subtype of the $\mathrm{GABA}_{\mathrm{A}}$ receptor $^{86}$. In rodents, two recent studies have shown that low doses of zolpidem administered daily from either day 1 or day 3 after stroke significantly improved motor recovery, though it did not affect the size of the lesion ${ }^{87,88}$. Zolpidem is safe to use in humans and has been used in diseases of consciousness after brain injury ${ }^{89}$. However, whether zolpidem might have a beneficial effect on motor recovery after stroke in humans is yet to be investigated. The hypothesis that zolpidem may have an effect on motor recovery is supported by anecdotal evidence from case studies showing improvements in post-stroke aphasia after zolpidem administration $^{90}$.

However, translating results from animal models to clinical populations has proved to be a significant problem in stroke research. This has been recently addressed by the Stroke Recovery and Rehabilitation Roundtable translational working group. Their guidelines aim to change the design of future preclinical studies in order to align the methods and outcome measures used in animal studies to those of clinical trials ${ }^{91}$. Improving translation can be achieved only by understanding the limitations of animal models of stroke, finding appropriate outcome measurements that can be compared between humans and animals, and designing preclinical and clinical experiments that can be easily compared in terms of dose and time of drug administration.

\section{Conclusions}

In this review, we discussed current understanding of the changes in the excitation-inhibition balance that characterise stroke recovery. While it is apparent that this balance undergoes significant changes during hyperacute, early, and chronic stroke, it is still unclear exactly what molecular and cellular mechanisms are underlying these changes during each stroke stage. GABA seems to play a central role in stroke recovery: increased GABAergic inhibition has been hypothesised to be protective during hyperacute stroke by counteracting glutamate-mediated excitotoxicity, while decreased GABAergic inhibition during early stroke has been proposed as a mechanism to support neuronal plasticity and subsequent improvements in motor functions. However, the role of inhibition in stroke recovery is much more complex. Investigating how changes in GABAergic inhibition affect overall cortical excitability and how they eventually relate to functional changes is necessary in order to better understand stroke pathophysiology.
1. C GBD 2016 Stroke Collaborators: Global, regional, and national burden of stroke, 1990-2016: A systematic analysis for the Global Burden of Disease Study 2016. Lancet Neurol. 2019; 18(5): 439-58. PubMed Abstract | Publisher Full Text | Free Full Text | Faculty Opinions Recommendation

2. Adamson J, Beswick A, Ebrahim S: Is stroke the most common cause of disability? J Stroke Cerebrovasc Dis. 2004; 13(4): 171-7. PubMed Abstract | Publisher Full Text

3. Hankey GJ: Stroke. Lancet. 2017; 389(10069): 641-654. PubMed Abstract | Publisher Full Text | Faculty Opinions Recommendation

4. Kang N, Cauraugh JH: Force control in chronic stroke. Neurosci Biobehav Rev. 2015; 52: 38-48.

PubMed Abstract | Publisher Full Text

5. Bhogal SK, Teasell RW, Foley NC, et al:: Community reintegration after stroke. Top Stroke Rehabil. 2003; 10(2): 107-29. PubMed Abstract | Publisher Full Text

6. Benjamin EJ, Blaha MJ, Chiuve SE, et al.: Heart Disease and Stroke Statistics-2017 Update: A Report From the American Heart Association. Circulation. 2017; 135(10): e146-e603. PubMed Abstract | Publisher Full Text | Free Full Text | Faculty Opinions Recommendation
7. Ovbiagele B, Goldstein LB, Higashida RT, et al.: Forecasting the future of stroke in the United States: A policy statement from the American Heart Association and American Stroke Association. Stroke. 2013; 44(8): 2361-75. PubMed Abstract | Publisher Full Text | Faculty Opinions Recommendation

8. Bentes C, Brigo F, Zelano J, et al.: Reperfusion therapies and poststroke seizures. Epilepsy Behav. 2020; 104(Pt B): 106524. PubMed Abstract | Publisher Full Text

9. Lawrence ES, Coshall C, Dundas R, et al:: Estimates of the prevalence of acute stroke impairments and disability in a multiethnic population. Stroke. 2001: 32(6): 1279-84.

PubMed Abstract | Publisher Full Text

10. Buntin MB, Colla CH, Deb $\mathrm{P}$, et al.: Medicare spending and outcomes after postacute care for stroke and hip fracture. Med Care. 2010; 48(9): 776-84 PubMed Abstract | Publisher Full Text | Free Full Text

11. Hubbard IJ, Parsons MW, Neilson C, et al.: Task-specific training: Evidence for and translation to clinical practice. Occup Ther Int. 2009; 16(3-4): 175-89. PubMed Abstract | Publisher Full Text

12. Smania N, Gandolfi M, Paolucci S, et al.: Reduced-intensity modified constraintinduced movement therapy versus conventional therapy for upper extremity rehabilitation after stroke: A multicenter trial. Neurorehabil Neural Repair. 2012; 26(9): 1035-45.

PubMed Abstract | Publisher Full Text 
13. Mehrholz J, Pohl M: Electromechanical-assisted gait training after stroke: A systematic review comparing end-effector and exoskeleton devices. $J$ Rehabil Med. 2012; 44(3): 193-9.

PubMed Abstract | Publisher Full Text

14. Winstein CJ, Stein J, Arena R, et al:: Guidelines for Adult Stroke Rehabilitation and Recovery: A Guideline for Healthcare Professionals From the American Heart Association/American Stroke Association. Stroke. 2016; 47(6): e98-e169. PubMed Abstract | Publisher Full Text

15. Johnstone A, Levenstein JM, Hinson EL, et al.: Neurochemical changes underpinning the development of adjunct therapies in recovery after stroke: $A$ role for GABA? J Cereb Blood Flow Metab. 2018; 38(9): 1564-1583. PubMed Abstract | Publisher Full Text | Free Full Text

16. Murphy TH, Corbett D: Plasticity during stroke recovery: From synapse to behaviour. Nat Rev Neurosci. 2009; 10(12): 861-72. PubMed Abstract | Publisher Full Text | Faculty Opinions Recommendation

17. Clarkson AN, Huang BS, Macisaac SE, et al:: Reducing excessive GABAmediated tonic inhibition promotes functional recovery after stroke. Nature. 2010; 468(7321): 305-9.

PubMed Abstract | Publisher Full Text | Free Full Text | Faculty Opinions Recommendation

18. Hess G, Aizenman CD, Donoghue JP: Conditions for the induction of long-term potentiation in layer II/III horizontal connections of the rat motor cortex. J Neurophysiol. 1996; 75(5): 1765-78.

PubMed Abstract | Publisher Full Text

19. Ziemann U, Muellbacher W, Hallett M, et al:: Modulation of practice-dependent plasticity in human motor cortex. Brain. 2001; 124(Pt 6): 1171-81. PubMed Abstract | Publisher Full Text

20. Talelli P, Greenwood RJ, Rothwell JC: Arm function after stroke: Neurophysiological correlates and recovery mechanisms assessed by transcranial magnetic stimulation. Clin Neurophysiol. 2006; 117(8): 1641-59. PubMed Abstract | Publisher Full Text

21. Rosso C, Lamy JC: Does Resting Motor Threshold Predict Motor Hand Recovery After Stroke? Front Neurol. 2018; 9: 1020. PubMed Abstract | Publisher Full Text | Free Full Text

22. Fisher RJ, Nakamura Y, Bestmann S, et al:: Two phases of intracortical inhibition revealed by transcranial magnetic threshold tracking. Exp Brain Res. 2002; 143(2): 240-8.

PubMed Abstract | Publisher Full Text

23. McDonnell MN, Orekhov $Y$, Ziemann U: Suppression of LTP-like plasticity in human motor cortex by the GABAB receptor agonist baclofen. Exp Brain Res. 2007; 180(1): 181-6.

PubMed Abstract | Publisher Full Text

24. Beaulieu LD, Flamand VH, Massé-Alarie $\mathrm{H}$, et al:: Reliability and minimal detectable change of transcranial magnetic stimulation outcomes in healthy adults: A systematic review. Brain Stimul. 2017; 10(2): 196-213. PubMed Abstract | Publisher Full Text

25. Cavaleri R, Schabrun SM, Chipchase LS: The number of stimuli required to reliably assess corticomotor excitability and primary motor cortical representations using transcranial magnetic stimulation (TMS): A systematic review and meta-analysis. Syst Rev. 2017; 6(1): 48. PubMed Abstract | Publisher Full Text | Free Full Text

26. Stagg CJ, Rothman DL: Magnetic Resonance Spectroscopy: Tools for Neuroscience Research and Emerging Clinical Applications. Magnetic resonance spectroscopy: tools for neuroscience research and emerging clinical applications. 2014; 376

Publisher Full Text

27. Stagg CJ, Bestmann S, Constantinescu AO, et al:: Relationship between physiological measures of excitability and levels of glutamate and GABA in the human motor cortex. J Physiol. 2011; 589(Pt 23): 5845-55. PubMed Abstract | Publisher Full Text | Free Full Text

28. Tremblay S, Beaulé V, Proulx S, et al:: Relationship between transcranial magnetic stimulation measures of intracortical inhibition and spectroscopy measures of GABA and glutamate+glutamine. J Neurophysiol. 2013; 109(5): 1343-9.

PubMed Abstract | Publisher Full Text | Free Full Text

29. Mooney RA, Cirillo J, Byblow WD: GABA and primary motor cortex inhibition in young and older adults: A multimodal reliability study. $J$ Neurophysiol. 2017; 118(1): 425-33.

PubMed Abstract | Publisher Full Text | Free Full Text | Faculty Opinions Recommendation

30. Dyke K, Pépés SE, Chen C, et al.: Comparing GABA-dependent physiological measures of inhibition with proton magnetic resonance spectroscopy measurement of GABA using ultra-high-field MRI. Neuroimage. 2017; 152 measuremer. 370 .

PubMed Abstract | Publisher Full Text | Free Full Text

31. Stagg CJ: Magnetic Resonance Spectroscopy as a tool to study the role of GABA in motor-cortical plasticity. Neuroimage. 2014; 86: 19-27. PubMed Abstract | Publisher Full Text

32. Baron JC: Mapping the ischaemic penumbra with PET: Implications for acute stroke treatment. Cerebrovasc Dis. 1999; 9(4): 193-201. PubMed Abstract | Publisher Full Text
33. Bernhardt J, Hayward KS, Kwakkel G, et al:: Agreed definitions and a shared vision for new standards in stroke recovery research: The Stroke Recovery and Rehabilitation Roundtable taskforce. Int J Stroke. 2017; 12(5): 444-450. PubMed Abstract | Publisher Full Text

34. Zeiler SR, Krakauer JW: The interaction between training and plasticity in the poststroke brain. Curr Opin Neurol. 2013; 26(6): 609-16. PubMed Abstract | Publisher Full Text | Free Full Text

35. Krakauer JW, Carmichael ST, Corbett D, et al:: Getting neurorehabilitation right: What can be learned from animal models? Neurorehabil Neural Repair. 2012; 26(8): 923-31.

PubMed Abstract | Publisher Full Text | Free Full Text

36. Lai TW, Zhang S, Wang YT: Excitotoxicity and stroke: Identifying novel targets for neuroprotection. Prog Neurobiol. 2014; 115: 157-88. PubMed Abstract | Publisher Full Text

37. Yang Q, Huang Q, Hu Z, et al.: Potential Neuroprotective Treatment of Stroke: Targeting Excitotoxicity, Oxidative Stress, and Inflammation. Front Neurosci. 2019; 13: 1036.

PubMed Abstract | Publisher Full Text | Free Full Text

38. Yan G, Dai Z, Xuan $Y$, et al:: Early metabolic changes following ischemia onset in rats: An in vivo diffusion-weighted imaging and $1 \mathrm{H}$-magnetic resonance spectroscopy study at 7.0 T. Mol Med Rep. 2015; 11(6): 4109-14. PubMed Abstract | Publisher Full Text | Free Full Text

39. AVERT Trial Collaboration group: Efficacy and safety of very early mobilisation within $24 \mathrm{~h}$ of stroke onset (AVERT): A randomised controlled trial. Lancet. 2015; 386(9988): 46-55.

PubMed Abstract | Publisher Full Text | Faculty Opinions Recommendation

40. Ruan L, Wang Y, Chen SC, et al:: Metabolite changes in the ipsilateral and contralateral cerebral hemispheres in rats with middle cerebral artery occlusion. Neural Regen Res. 2017; 12(6): 931-937. PubMed Abstract | Publisher Full Text | Free Full Text

41. Griffin CE 3rd, Kaye AM, Bueno FR, et al:: Benzodiazepine pharmacology and central nervous system-mediated effects. Ochsner J. 2013; 13(2): 214-23. PubMed Abstract | Free Full Text

42. Sydserff SG, Cross AJ, Green AR: The neuroprotective effect of chlormethiazole on ischaemic neuronal damage following permanent middle cerebral artery ischaemia in the rat. Neurodegeneration. 1995; 4(3): 323-8. PubMed Abstract | Publisher Full Text

43. Marshall JW, Cross AJ, Ridley RM: Functional benefit from clomethiazole treatment after focal cerebral ischemia in a nonhuman primate species. Exp Neurol. 1999; 156(1): 121-9.

PubMed Abstract | Publisher Full Text

44. L Liu J, Zhang J, Wang LN: Gamma aminobutyric acid (GABA) receptor agonists for acute stroke. Cochrane Database Syst Rev. 2018; 10(10): CD009622.

PubMed Abstract | Publisher Full Text | Free Full Text | Faculty Opinions Recommendation

45. Simon GE, Ludman EJ: Outcome of new benzodiazepine prescriptions to older adults in primary care. Gen Hosp Psychiatry. 2006; 28(5): 374-8. PubMed Abstract | Publisher Full Text | Free Full Text

46. Olfson M, King M, Schoenbaum M: Benzodiazepine use in the United States. JAMA Psychiatry. 2015; 72(2): 136-42.

PubMed Abstract | Publisher Full Text | Faculty Opinions Recommendation

47. Colin O, Labreuche $\mathrm{J}$, Deguil $\mathrm{J}$, et al:: Preadmission use of benzodiazepines and stroke outcomes: The Biostroke prospective cohort study. BMJ Open. 2019; 9(1): e022720.

PubMed Abstract | Publisher Full Text | Free Full Text

48. Duncan PW, Goldstein LB, Matchar D, et al:: Measurement of motor recovery after stroke. Outcome assessment and sample size requirements. Stroke. 1992; 23(8): 1084-9.

PubMed Abstract | Publisher Full Text

49. Huang Q, Li C, Xia N, et al.: Neurochemical changes in unilateral cerebral hemisphere during the subacute stage of focal cerebral ischemia-reperfusion in rats: An ex vivo ${ }^{1} \mathrm{H}$ magnetic resonance spectroscopy study. Brain Res. 2018; 1684: 67-74 PubMed Abstract | Publisher Full Text

50. McDonnell MN, Stinear CM: TMS measures of motor cortex function after stroke: A meta-analysis. Brain Stimul. 2017; 10(4): 721-34. PubMed Abstract | Publisher Full Text | Faculty Opinions Recommendation

51. Kim YK, Yang EJ, Cho K, et al.: Functional Recovery After Ischemic Stroke Is Associated With Reduced GABAergic Inhibition in the Cerebral Cortex: A GABA PET Study. Neurorehabil Neural Repair. 2014; 28(6): 576-83. PubMed Abstract | Publisher Full Text

52. Cirillo J, Mooney RA, Ackerley SJ, et al.: Neurochemical balance and inhibition at the subacute stage after stroke. J Neurophysiol. 2020; 123(5) 1775-90.

PubMed Abstract | Publisher Full Text | Faculty Opinions Recommendation

53. Swayne OBC, Rothwell JC, Ward NS, et al:: Stages of motor output reorganization after hemispheric stroke suggested by longitudinal studies of cortical physiology. Cereb Cortex. 2008; 18(8): 1909-22. PubMed Abstract | Publisher Full Text | Free Full Text 
54. Schambra HM, Ogden RT, Martínez-Hernández IE, et al:: The reliability of repeated TMS measures in older adults and in patients with subacute and chronic stroke. Front Cell Neurosci. 2015; 9: 335.

PubMed Abstract | Publisher Full Text | Free Full Text

55. Głodzik-Sobańska L, Słowik A, Kozub J, et al:: GABA in ischemic stroke. Proton magnetic resonance study. Med Sci Monit. 2004; 10 Suppl 3: 88-93. PubMed Abstract

56. Blicher JU, Near J, Næss-Schmidt E, et al.: GABA levels are decreased after stroke and GABA changes during rehabilitation correlate with motor improvement. Neurorehabil Neural Repair. 2015; 29(3): 278-86. PubMed Abstract | Publisher Full Text | Free Full Text

57. Mooney RA, Ackerley SJ, Rajeswaran DK, et al.: The Influence of Primary Motor Cortex Inhibition on Upper Limb Impairment and Function in Chronic Stroke: A Multimodal Study. Neurorehabil Neural Repair. 2019; 33(2): 130-40. PubMed Abstract | Publisher Full Text | Faculty Opinions Recommendation

58. Ferreiro de Andrade KN, Conforto $A B$ : Decreased short-interval intracortical inhibition correlates with better pinch strength in patients with stroke and good motor recovery. Brain Stimul. 2018; 11(4): 772-4. PubMed Abstract | Publisher Full Text | Free Full Text

59. O'Shea J, Boudrias MH, Stagg CJ, et al:: Predicting behavioural response to TDCS in chronic motor stroke. Neuroimage. 2014; 85 Pt 3(Pt 3): 924-33. PubMed Abstract | Publisher Full Text | Free Full Text

60. Liepert J, Bauder $\mathrm{H}$, Wolfgang HR, et al.: Treatment-induced cortical reorganization after stroke in humans. Stroke. 2000; 31(6): 1210-6. PubMed Abstract | Publisher Full Text

61. Stinear JW, Byblow WD: Rhythmic bilateral movement training modulates corticomotor excitability and enhances upper limb motricity poststroke: A pilot study. J Clin Neurophysiol. 2004; 21(2): 124-31. PubMed Abstract | Publisher Full Text

62. Taub E, Uswatte G, Mark VW: The functional significance of cortical reorganization and the parallel development of $\mathrm{Cl}$ therapy. Front Hum Neurosci. 2014; 8: 396 . PubMed Abstract | Publisher Full Text | Free Full Text

63. Abdullahi A, Truijen S, Saeys W: Neurobiology of Recovery of Motor Function after Stroke: The Central Nervous System Biomarker Effects of ConstraintInduced Movement Therapy. Neural Plast. 2020; 2020: 9484298. PubMed Abstract | Publisher Full Text | Free Full Text

64. Cash RFH, Ziemann U, Murray K, et al.: Late cortical disinhibition in human motor cortex: A triple-pulse transcranial magnetic stimulation study. J Neurophysiol. 2010; 103(1): 511-8. PubMed Abstract | Publisher Full Text

65. Reynolds $\mathrm{C}$, Ashby $\mathrm{P}$ : Inhibition in the human motor cortex is reduced just before a voluntary contraction. Neurology. 1999; 53(4): 730-5. PubMed Abstract | Publisher Full Text

66. Hummel FC, Steven B, Hoppe J, et al.: Deficient intracortical inhibition (SICI) during movement preparation after chronic stroke. Neurology. 2009; 72(20): 1766-72.

PubMed Abstract | Publisher Full Text | Free Full Text

67. Dupont-Hadwen J, Bestmann S, Stagg CJ: Motor training modulates intracortical inhibitory dynamics in motor cortex during movement preparation. Brain Stimul. 2019; 12(2): 300-8.

PubMed Abstract | Publisher Full Text | Free Full Text

68. Rothwell JC: Can Motor Recovery in Stroke Be Improved by Non-invasive Brain Stimulation? In Progress in Motor Control: Theories and Translations. (eds. Laczko, J. \& Latash, M. L.) Springer International Publishing, 2016; 313-323. Publisher Full Text

69. Hummel FC, Celnik P, Pascual-Leone A, et al.: Controversy: Noninvasive and invasive cortical stimulation show efficacy in treating stroke patients. Brain Stimul. 2008; 1(4): 370-82. PubMed Abstract | Publisher Full Text

70. Bao SC, Khan A, Song R, et al:: Rewiring the Lesioned Brain: Electrical Stimulation for Post-Stroke Motor Restoration. J Stroke. 2020; 22(1): 47-63. PubMed Abstract | Publisher Full Text | Free Full Text

71. Fisicaro F, Lanza G, Grasso AA, et al.: Repetitive transcranial magnetic stimulation in stroke rehabilitation: Review of the current evidence and pitfalls. Ther Adv Neurol Disord. 2019; 12: 1756286419878317. PubMed Abstract | Publisher Full Text | Free Full Text

72. Grefkes C, Fink GR: Recovery from stroke: Current concepts and future perspectives. Neurol Res Pract. 2020; 2: 17. PubMed Abstract | Publisher Full Text | Free Full Text | Faculty Opinions Recommendation

73. Kang N, Summers JJ, Cauraugh JH: Transcranial direct current stimulation facilitates motor learning post-stroke: A systematic review and meta-analysis.
J Neurol Neurosurg Psychiatry. 2016; 87(4): 345-55. PubMed Abstract | Publisher Full Text

74. Subramanian SK, Prasanna SS: Virtual Reality and Noninvasive Brain Stimulation in Stroke: How Effective Is Their Combination for Upper Limb Motor Improvement?-A Meta-Analysis. PM R. 2018; 10(11): 1261-70. PubMed Abstract | Publisher Full Text

75. O'Brien AT, Bertolucci F, Torrealba-Acosta G, et al:: Non-invasive brain stimulation for fine motor improvement after stroke: A meta-analysis. Eur Neurol. 2018; 25(8): 1017-26.

PubMed Abstract | Publisher Full Text

76. Darmani G, Zipser CM, Böhmer GM, et al.: Effects of the Selective $\alpha 5-$ GABAAR Antagonist S44819 on Excitability in the Human Brain: A TMS-EMG and TMSEEG Phase I Study. J Neurosci. 2016; 36(49): 12312-20. PubMed Abstract | Publisher Full Text | Free Full Text

77. Etherington LA, Mihalik B, Pálvölgyi A, et al:: Selective inhibition of extrasynaptic $\alpha 5-G A B A_{A}$ receptors by $S 44819$, a new therapeutic agent. Neuropharmacology. 2017; 125: 353-64. PubMed Abstract | Publisher Full Text

78. Wang YC, Dzyubenko E, Sanchez-Mendoza EH, et al:: Postacute Delivery of GABA $_{A} \alpha 5$ Antagonist Promotes Postischemic Neurological Recovery and Peri-infarct Brain Remodeling. Stroke. 2018; 49(10): 2495-503. PubMed Abstract | Publisher Full Text | Free Full Text

79. Chabriat $\mathrm{H}$, Bassetti $\mathrm{CL}$, Marx $\mathrm{U}$, et al:: Safety and efficacy of GABA $\alpha \mathbf{0}$ antagonist $S 44819$ in patients with ischaemic stroke: A multicentre, doubleblind, randomised, placebo-controlled trial. Lancet Neurol. 2020; 19(3): 226-33. PubMed Abstract | Publisher Full Text | Faculty Opinions Recommendation

80. Lake EMR, Chaudhuri J, Thomason L, et al:: The effects of delayed reduction of tonic inhibition on ischemic lesion and sensorimotor function. $J$ Cereb Blood Flow Metab. 2015; 35(10): 1601-9.

PubMed Abstract | Publisher Full Text | Free Full Text |

Faculty Opinions Recommendation

81. CHe WM, Ying-Fu L, Wang $\mathrm{H}$, et al:: Delayed treatment of $\alpha .5$ GABAA receptor inverse agonist improves functional recovery by enhancing neurogenesis after cerebral ischemia-reperfusion injury in rat MCAO model. Sci Rep. 2019 9(1): 2287.

PubMed Abstract | Publisher Full Text | Free Full Text | Faculty Opinions Recommendation

82. Orfila JE, Grewal H, Dietz RM, et al.: Delayed inhibition of tonic inhibition enhances functional recovery following experimental ischemic stroke. $J$ Cereb Blood Flow Metab. 2019; 39(6): 1005-14.

PubMed Abstract | Publisher Full Text | Free Full Text

83. Alia C, Spalletti C, Lai $S$, et al:: Reducing $\mathrm{GABA}_{\mathrm{A}}$-mediated inhibition improves forelimb motor function after focal cortical stroke in mice. Sci Rep. 2016; 6: 37823.

PubMed Abstract | Publisher Full Text | Free Full Text

84. Neumann S, Boothman-Burrell L, Gowing EK, et al.: The Delta-Subunit Selective $\mathrm{GABA}_{A}$ Receptor Modulator, DS2, Improves Stroke Recovery via an Antiinflammatory Mechanism. Front Neurosci. 2019; 13: 1133. PubMed Abstract | Publisher Full Text | Free Full Text

85. Clarkson AN, Boothman-Burrell L, Dósa Z, et al.: The flavonoid, 2'-methoxy-6methylflavone, affords neuroprotection following focal cerebral ischaemia. J Cereb Blood Flow Metab. 2019; 39(7): 1266-82. PubMed Abstract | Publisher Full Text | Free Full Text

86. Crestani $\mathrm{F}$, Martin JR, Möhler $\mathrm{H}$, et al.: Mechanism of action of the hypnotic zolpidem in vivo. Br J Pharmacol. 2000; 131(7): 1251-4. PubMed Abstract | Publisher Full Text | Free Full Text

87. Hiu T, Farzampour Z, Paz JT, et al:: Enhanced phasic GABA inhibition during the repair phase of stroke: A novel therapeutic target. Brain. 2016; 139(Pt 2): the repair 80 .

PubMed Abstract | Publisher Full Text | Free Full Text

88. Oh MK, Yoon KJ, Lee YT, et al.: Effect of zolpidem on functional recovery in a rat model of ischemic stroke. J Int Med Res. 2018; 46(1): 249-57. PubMed Abstract | Publisher Full Text | Free Full Text

89. Bomalaski MN, Claflin ES, Townsend W, et al:: Zolpidem for the Treatment of Neurologic Disorders: A Systematic Review. JAMA Neurol. 2017; 74(9): 1130-9. PubMed Abstract | Publisher Full Text

90. Cohen L, Chaaban B, Habert MO: Transient improvement of aphasia with zolpidem. N Engl J Med. 2004; 350(9): 949-50. PubMed Abstract | Publisher Full Text

91. Corbett D, Carmichael ST, Murphy TH, et al:: Enhancing the alignment of the preclinical and clinical stroke recovery research pipeline: Consensusbased core recommendations from the Stroke Recovery and Rehabilitation Roundtable translational working group. Int J Stroke. 2017; 12(5): 462-71. PubMed Abstract | Publisher Full Text | Faculty Opinions Recommendation 